\title{
CLEVELAND METROPARKS AND THE LAKE ERIE COAST: NATURAL CAPITAL AND RESILIENCE IN THE FOREST CITY
}

\author{
DEBRA K. BERRY, KELLY B. COFFMAN \& BRIAN M. ZIMMERMAN \\ Cleveland Metroparks, USA
}

\begin{abstract}
Cleveland Metroparks conserves natural resources and provides recreation and education to over 17 million visitors annually. Founded in 1917, this natural-area park system protects major riparian corridors leading to Lake Erie, the southernmost Great Lake and part of Earth's largest surface freshwater system. The purpose of this paper is to demonstrate and quantify the value of the park system's natural capital: 23,200 acres of parkland and nearly four miles of Lake Erie shoreline. The Trust for Public Land conducted a 2013 study which determined that Cleveland Metroparks provides over $\$ 855$ million in economic benefits to the regional economy annually. The study used conventional methodology, resulting in a conservative and defensible dollar value. The contributions of parks, open space, trails, and other aspects of natural capital to community health and resilience continue to be studied and quantified. This paper compiles and presents the spectrum of benefits provided by vibrant parks, open space, and trails and their crucial role in today's resilient coastal cities.
\end{abstract}

Keywords: natural capital, resilience, Cleveland Metroparks, stewardship, economic impact, trails, Ohio.

\section{INTRODUCTION}

Cleveland has been known as the "Forest City" since the early $19^{\text {th }}$ century. It is no coincidence that the area's forests and other natural capital fueled Cleveland's growth to become one of the 10 largest cities in the US from 1900 to 1960. Natural capital, defined as "the stock of ecosystems that yields a renewable flow of goods and services that underpin the economy and provide inputs and direct and indirect benefits to businesses and society" [1] was readily available in Cleveland in the form of forests, minerals, prime farmland, and abundant fresh water. The initial use of natural capital took the form of raw resources to support agriculture and manufacturing. As part of national and local social movements and reforms beginning in the late 1800s and early 1900s, city leaders recognized that the region's natural resources held more value than just for production and laid the groundwork for the protection of swaths of park and natural lands for the benefit of their citizenry.

Founded in 1917, Cleveland Metroparks legacy of stewardship now enables the community to capitalize on other significant facets of natural capital provided by 23,200 acres of conserved streams, forests, and corridors of habitat, trails, and intrinsic scenic beauty. The Park District also contributes to the social fabric of the region: park areas and facilities host gatherings, education sessions, recreation programs, and provide a backdrop for casual interaction between all residents of northeast Ohio. While there is value to the environment in the physical carrying capacity of the parks for stormwater and carbon capture, it is their social aspect to help build community cohesion that may contribute most to resilience

\section{THE FOREST CITY}

Cleveland was established in 1796 at the confluence of the Cuyahoga River and Lake Erie. Lake Erie is the southernmost of the Great Lakes, the world's largest surface freshwater system. Alexis de Tocqueville visited the area in the 1830s when researching Democracy in 
America. His journal notes surprise at encountering a civilized community with elegant houses emerging from a dense forest of immense trees. As noted by de Tocqueville, the abundant forests that once surrounded Cleveland give the city its nickname of the "Forest City."

Growth occurred slowly until the 1820s, when the completion of the Ohio and Erie Canal linked Northeast Ohio to other Great Lakes ports, New York, and from there the world, providing the fastest transportation available at the time. These resources combined with an influx of immigrants to create a thriving city. Both were leveraged by inventors and entrepreneurs to build Cleveland into a major manufacturing and industrial center.

By the early 1900 s, Cleveland was the fifth-largest city in the US with a population equal to that of Madrid, San Francisco, or Rome. John D. Rockefeller's Standard Oil and other international companies generated extraordinary wealth for the city's magnates, leading to Euclid Avenue's glamorous "Millionaire's Row" of mansions, said to rival the ChampsÉlysées in Paris; however, there were tremendous disparities in the rapidly urbanized community.

\section{CIVITISM}

Similar challenges across the country led to the Progressive Era, a national movement to improve living standards in urban areas. Progressive Era initiatives in Cleveland included the development of a civic center based on Daniel Burnham's Group Plan and efforts to address the impacts of industrialization, immigration, and urbanization. Actions took the form of government reforms as well as the founding of private institutions to improve quality of life.

The term civitism was coined by Mayor Newton D. Baker in 1912 to describe the creation of a sense of pride in all citizens for Cleveland [2]. Civitism can be equated to the social equity and community cohesion concepts of today, key building blocks of sustainability and resilience. Civitism in Cleveland was bolstered by the founding of the Cleveland Orchestra, Cleveland Museum of Art, Western Reserve Historical Society, Cleveland Museum of Natural History, the Cleveland Foundation (the first community charitable foundation in the US), the Federation for Charity and Philanthropy (a forerunner of United Way), and Cleveland Metroparks.

Cleveland City Engineer William A. Stinchcomb promoted the idea of an outer system of parks and boulevards as early as 1905 . His journals document several goals: protection of the scenic river valleys surrounding Cleveland, conservation of forests and natural resources, and opportunities for city dwellers to relieve the tensions of urban life. State enabling legislation was introduced by supporters "to provide for the conservation of natural resources by the creation, development, and improvement of park districts" [3]. The Cleveland Metropolitan Park District, now known as Cleveland Metroparks, was created in July 1917. A conceptual map was publicized in 1920 (Fig. 1).

\section{CLEVELAND METROPARKS}

Protection of natural capital across multiple jurisdictions is often challenging. The Progressive Era idealism behind the creation of Cleveland Metroparks anticipated this and other challenges and created a stable underlying structure outside the realm of traditional politics. The Park District is overseen by a three-person Board of Park Commissioners appointed by the senior county Probate Judge. The Board hires a Chief Executive Officer to staff and administer the district. Funding is independent of any municipal or county budgets, and includes a designated property tax, grants, donations, and enterprise operations. The park district has 645 budgeted full-time staff and an annual operating and capital budget of nearly $\$ 142$ million dollars [4]. The district operates on a debt-free basis, with no capital obligations or unfunded liabilities. 


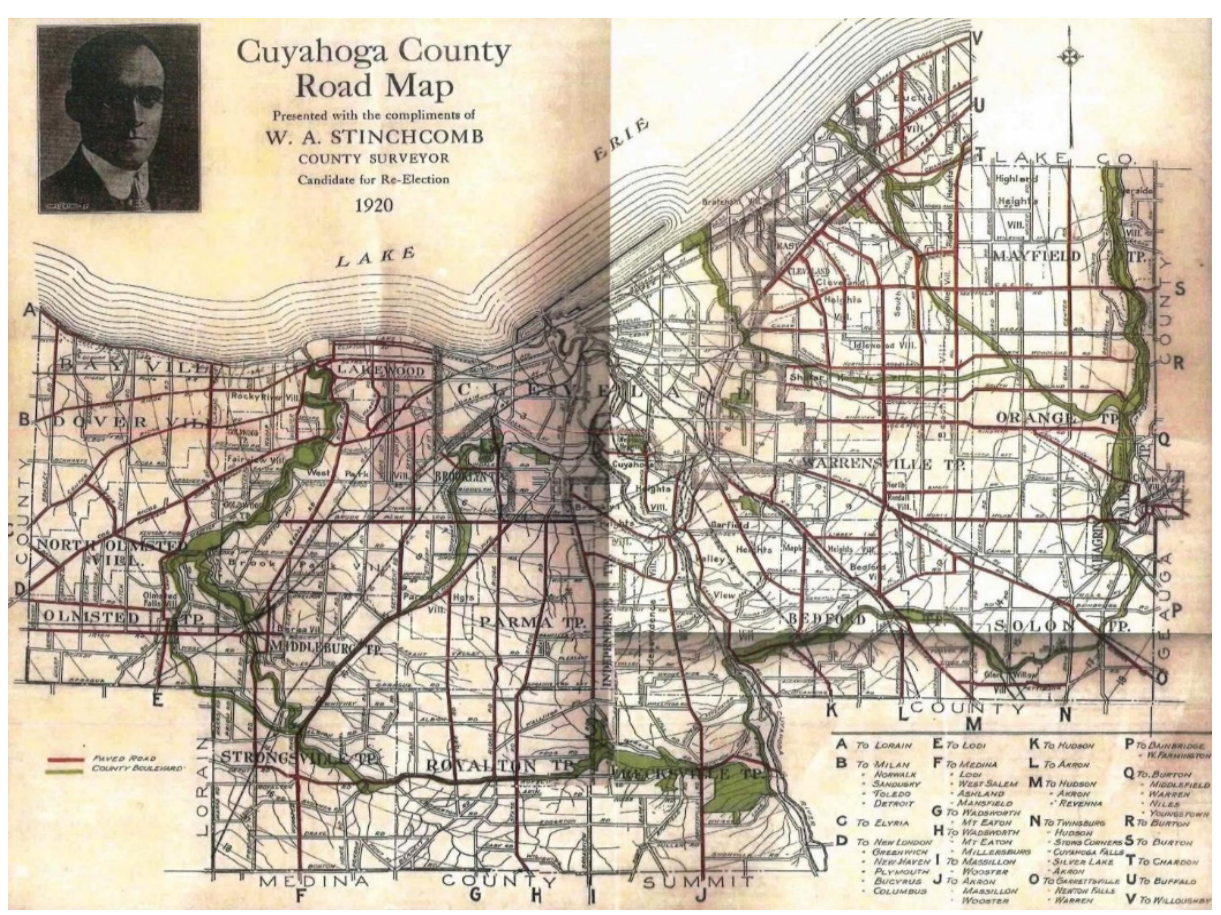

Figure 1: 1920 map of proposed metropolitan park system.

Today the Park District, also known as the Emerald Necklace, manages 23,200 acres in 47 communities. Land acquisition has taken place steadily over time, in fact the Park District has grown $22 \%$ in the past 30 years, adding 4271 at a time when development pressures are higher than ever. Natural capital protected in perpetuity includes nearly 18,000 acres of forest, 200 miles of streams and tributaries, 2700 wetland areas, and nearly four miles of Lake Erie shoreline. The 300 miles of trails, hundreds of picnic areas, and five nature centers help connect guests with the resources of the parks and provide a range of opportunities from recreation to the passive enjoyment of nature.

\section{INDUSTRY AND DEVELOPMENT}

Cleveland's industry and booming population transformed the natural landscape described by de Tocqueville. The industry created great wealth but also left a legacy of pollution, leaving several generations of Clevelanders without any experience of connecting to the waterfront. An oil slick on the Cuyahoga River caught fire in 1969, leading to national notoriety for the city and became a catalyst for the modern environmental movement. Within two years of the fire, Congress passed the Clean Water Act and the US Environmental Protection Agency (EPA) was established. The river, while still important to industry, has been remediated to the point that Clevelanders now embrace the waterfront and are utilizing it for recreation and redevelopment.

Air and water pollution along with other urban challenges led to the outmigration of much of Cleveland's population in the second half of the twentieth century. Northeast Ohio (defined as the eight-county area of Cuyahoga, Geauga, Lake, Lorain, Medina, Portage, Stark, and Summit Counties) grew from a population of 1.6 million in 1920 to a population of 3.1 million in 2010 (Fig. 2). Aided by easy highway access, development in suburbs and 


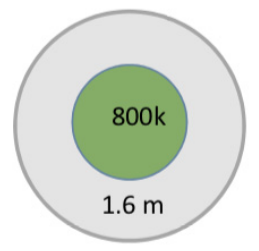

1920 Population

Cleveland: 800,000

Eight County Region: 1,600,000

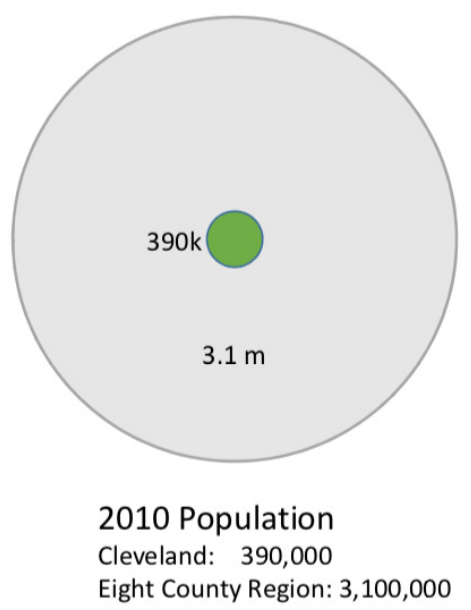

Eight County Region: 3,100,000

Figure 2: Population of Cleveland and surrounding region in 1920 and 2010.

outlying counties expanded. When compared to 1920 , one county's population is $800 \%$ higher, while the city of Cleveland's population is $50 \%$ lower. This pattern of sprawl consumed much of the region's natural capital, yet Cleveland Metroparks has remained a constant and reliable community asset.

\section{REGIONAL EFFORTS AND RESURGENCE}

The protection of prime farmland, stewardship of water resources, and conservation of forests and sensitive areas took on new urgency as the region's population sprawled away from urban centers. By 1967, seven of the eight counties in the region had established a natural area park system under the same state enabling legislation as Cleveland Metroparks. Grassroots activism in the led to the 1974 designation of Cuyahoga Valley National Recreation Area, later to become Cuyahoga Valley National Park (CVNP). The only national park in Ohio, CVNP protects 33,000 acres midway between Cleveland and Akron.

Efforts to address regional issues have taken place with several multi-jurisdictional planning efforts. These plans engaged a range of stakeholders to identify strategies for community improvement and natural area protection.

\subsection{Key regional efforts}

1. Connecting to Nature in Northeast Ohio (2000), a consortium of the area's eight Metro Parks agencies, CVNP and other stakeholders to "Identify opportunities for open space conservation, river corridor protection, and trail linkages."

2. Connecting Cleveland, The Waterfront District Plan (2004), a city of Cleveland effort involving the public, 6 partners, and 48 advisory committee members in a plan to "Shape the Lakefront as the most vital element in the transformation of Cleveland as a place to live, work, and play."

3. Common Ground: the land protection report for northern Ohio (2012), a publication of the Western Reserve Land Conservancy project including 19 area agencies studying a 14-county area and promoting the region's future as a "healthy, vibrant place with beautiful parks, clean rivers and lakes, productive farmland, and amazing natural land." 
4. Vibrant NEO 2040: A Vision, Framework, and Action Products for Our Future [4] (2000-2013, with ongoing implementation), the Northeast Ohio Sustainable Communities Consortium (NEOSCC), a first of its kind effort led by regional planning organizations and stakeholders representing 12 counties with robust public engagement. The work was funded by a 4.25 million federal grant, and the initiative seeks to create a vibrant, resilient, and sustainable Northeast Ohio. Recommendations to expand the existing bicycle and trail system, improve regional connections to transit hubs and connect with the existing network of parks, trails, lakes and rivers as part of a set of strategies to make the region more sustainable and competitive. By focusing investments in established communities, especially within Cuyahoga County, carrying costs for the region can be reduced and quality of life improved.

Cleveland Metroparks participated in each of these regional efforts while consistently working quietly in the background to realize Stinchcomb's original vision for the Emerald Necklace. Land acquisition, and more recently habitat restoration efforts, are a consistent priority. Stewardship is the foundation of the Park District's work, however a greater understanding of the value these resources provide to the community emerged in the latest strategic plan, initiated in 2010.

Spurred by the 2008 foreclosure crisis and other challenges in Cuyahoga County and informed by regional efforts noted above, the 2012 Emerald Necklace Centennial Plan was the organization's first effort to look outside park boundaries and identify a larger role for Cleveland Metroparks. The plan laid out seven key directions to leverage the park district's positive impact for greater community benefit. It was supported by an Economic Impact Study conducted by a non-profit conservation organization, the Trust for Public Land (TPL) [5].

\section{THE ECONOMIC CASE FOR CLEVELAND METROPARKS}

Cleveland Metroparks provides over $\$ 855$ million in economic benefits to the regional economy annually. This figure was established by a 2013 study performed by the TPL. TPL is a non-profit conservation organization with expertise in assessing economic benefits of parks and open space throughout the US.

The study used conventional methodology to quantify benefits, ranging from higher real estate values and increased tax revenue for residential properties within 500' of park lands, to reduction in storm water runoff, improvements to air quality, recreation and tourism impact, and health cost savings attributable to park visits. Standard values exist for these components. The study utilized the lower side of these values, resulting in a conservative and defensible dollar value.

\subsection{Key findings}

\subsubsection{Property value and tax revenue}

1. Enhanced property value (not included in annual figure)

2. Homes within 500 feet of Cleveland Metroparks parks and trails have a total market value of $\$ 2.76$ billion

3. Parks and trails add a market value premium between $2 \%$ (trails) and $5 \%$ (parks), providing an additional $\$ 123$ million asset value

4. Additional property tax revenue totals $\$ 3.09$ million annually 


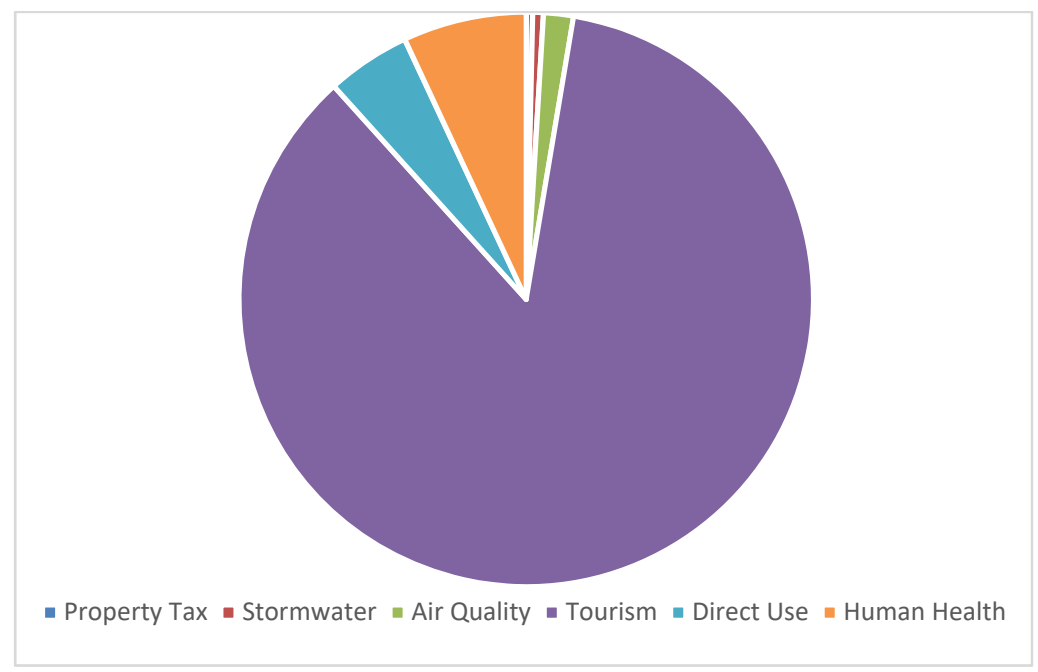

Figure 3: Annual economic benefits provided by Cleveland Metroparks.

\subsubsection{Ecosystem services}

1. The parks impervious surfaces slow and store stormwater runoff. This green infrastructure provides the equivalent of $\$ 5.12$ million in annual benefit.

2. The vegetation within Cleveland Metroparks, particularly the forest canopy, removes pollutants from the air and improve air quality equating to $\$ 14.4$ million in air pollution removal services.

\subsubsection{Tourism and recreation}

1. Cuyahoga County experienced $\$ 6.6$ billion in tourism sales in 2011 , generating $\$ 194$ million in sales tax. Outdoor recreation in Ohio generates $\$ 17.4$ billion in consumer spending and 196,000 jobs.

2. Visiting the outdoors is the primary purpose of $11 \%$ of visitors to Cuyahoga County. $\$ 733$ million in tourism spending for travel can be attributed to parks and trails annually.

3. \$40.4 million in direct use value (playgrounds, hiking, picnicking, wildlife viewing, concerts, golf).

4. The value provided by increased human health due to increased physical activity levels equates to $\$ 59.5$ million annually.

TPL's report confirms the value delivered by Cleveland Metroparks and helped bolster support of one of Northeast Ohio's most highly regarded public entities. In 2013, the organization passed a 10-year property tax levy (1.8 mill renewal and 0.9 mill increase) with $70 \%$ of the vote, providing a stable underpinning to pursue the goals of the Emerald Necklace Centennial Plan. Cleveland Metroparks has continued to manage the legacy parks of the Emerald Necklace while expanding operations and land holdings to take on new parks along Lake Erie, build a system of River and Lake Trails along the downtown riverfront, and to bring the positive impacts of parks and trails to the core of the community. Brief case studies of Edgewater Park and the River and Lake Trails are illustrated below: 


\subsubsection{Case study: Edgewater Park}

Edgewater Park is a 147-acre park along the Lake Erie shore. The park dates to 1894 and features the largest beach in Cleveland. It is bounded by two city of Cleveland neighborhoods: Edgewater to the west and Detroit-Shoreway to the south. Detroit-Shoreway, a dense, historically working class neighborhood dealing with the loss of manufacturing jobs and declining property value, is disconnected from the park by a railroad corridor and highway. Both neighborhoods are in close proximity to the park and the lakefront yet not necessarily valued for these amenities. The lakefront was not appreciated and the park was underutilized due perceptions of being unsafe, along with water quality problems caused by combined sewer overflow events.

The Edgewater area was a focus of the 2004 Connecting Cleveland Waterfront District Plan, which led to a state of Ohio funding commitment of $\$ 95$ million to rebuild the highway as a lower speed boulevard. The project includes constructing a roadway link to the lakefront, improving two tunnel access points for bikes and pedestrians, and creating a lakefront bike trail. Another result of the plan and ongoing community dialogue was the transfer of the 387-acre Lakefront State Park to Cleveland Metroparks in 2013. The Northeast Ohio Regional Sewer District initiated a $\$ 3$ billion plan, reducing overflow events to less than once a year. Water quality information is shared daily online and at the beach.

Mowing, maintenance, improved staff and ranger presence, and the immediate addition of robust event programming quickly transformed public perception and began to return Edgewater Park to a premier destination. Arts organizations, community development corporations, and investments in streetscapes and placemaking interventions in the neighborhoods helped generate developer interest and create a vibrant sense of community. These actions cumulatively led to the redevelopment and resurgence of the Detroit-Shoreway and Edgewater neighborhoods, recognized as one of the most active and in-demand real estate markets in Cleveland.

The success at Edgewater demonstrates the role of active stewardship and management in fully recognizing the intrinsic value of natural capital. Edgewater Park was recently announced as the site of the USA Triathlon Age-Group National Championships in 2018 and 2019 , which is expected to generate $\$ 7$ million in economic impact for the community. The improvements to property value, neighborhood vitality, recreation and health benefits, and tourism are only part of the story: repopulating the urban core and building Cleveland's civitism will deliver lasting positive outcomes.

\subsubsection{Case study: River and Lake Trail Network}

Cleveland Metroparks is working with numerous partners to implement a new network of bike and pedestrian trails in the Cuyahoga River valley (known as the Flats) and Lake Erie near downtown Cleveland. The Flats were once lined with warehouses, steel mills, oil refineries, and other manufacturing facilities that helped make Cleveland an industrial giant. Numerous rail lines fed in and out of the Flats through the west side neighborhoods to supply and ship materials. The industries provided thousands of jobs for people of the surrounding neighborhoods; however, as manufacturing has declined, opportunities have shifted and most jobs are located further away. With industry largely gone, neighborhoods are left close to the river and lake but without recreational amenities. Decades of isolation, reduced property values and disparity in neighborhoods due to public transportation policy and funding decisions caused these once dense and connected areas to be broken apart by highways and rail lines.

Efforts to protect, restore, and reactivate the river corridor as a recreational amenity began with grassroots environmental advocacy in the 1960s, including a vision for the Towpath 
Trail. The Towpath Trail is a regional route, linking Cleveland to Cuyahoga Valley National Park and points south. It is part of a multi-state effort to connect Cleveland and Pittsburgh via off-road trails and is the northern portion of a statewide trail from Lake Erie to the Ohio River. The 110-mile Towpath Trail, now more than 90\% complete, will eventually begin where the Ohio and Erie Canal meets the Cuyahoga River in downtown Cleveland.

The Towpath Trail corridor forms the spine of a new system of trail infrastructure will help revitalize disconnected neighborhoods by providing a safe transportation alternative link to jobs and recreation, including parks along the Cuyahoga River and Lake Erie. Over $\$ 74$ million is being invested in trails and linear park infrastructure for final stages of the Towpath Trail (Harvard Ave. to Canal Basin Park) and for links between the Cuyahoga River, Lake Erie, downtown Cleveland and surrounding neighborhoods. Projects include The Cleveland Foundation Centennial Trail, and the Re-Connecting Cleveland projects: Wendy Park Bridge, Whiskey Island Connector, Red Line Greenway, Cleveland Lakefront Bikeway Connector, and Canal Basin Park.

Cleveland Metroparks is a key supporter of the newly expanded River and Lake Trail Network. The Park District will manage and operate the proposed trails. It has leveraged millions in outside funding, including a \$7.95 million-dollar federal grant for the Re-Connecting Cleveland projects funded through the Transportation Investment Generating Economic Recovery (TIGER) program. When complete, this addition to Cleveland's trail infrastructure is estimated to provide a 3:1 benefit-cost return, as calculated in detail for the Re-Connecting Cleveland projects [6]. The benefit calculation is based on reductions in pedestrian and bicyclist injuries and fatalities, improved health through active transportation, reduced health care costs, and reduced auto use and traffic congestion, leading to reduced air pollution and user savings. Tourism impacts were not calculated, but have the potential to deliver millions in community benefit. As with the Edgewater Park Case Study, perhaps the most valuable benefits will arise from vibrant neighborhoods in the urban core.

\section{RESILIENCE AND THE NEXT 100 YEARS}

Resilience is defined as "the capacity of individuals, communities, institutions, businesses, and systems within a city to survive, adapt, and grow no matter what kinds of chronic stresses and acute shocks they experience" [7]. Cleveland Metroparks imparts a foundation of resilience to the community through a baseline of reliable natural capital. While the city of Cleveland and the northeast Ohio region have transformed over the past one hundred years, the organizational structure, funding, and vision of Cleveland Metroparks has remained constant over time. The Progressive Era framework has weathered economic booms and busts, development and expansion, downturns and abandonment, and reinvestment and revival.

Climate change is expected to impact Cleveland in the form of more extreme weather and storm events. Cleveland Metroparks contributes reliable and consistent management and operations, positive community engagement and support, highly functional natural systems that process and mitigate extreme weather, and community cohesion supported by shared experiences and civic pride, which harkens back to Mayor Baker and the concept of civitism.

Lake Erie, the Cuyahoga River, and the forests, minerals, and agricultural abundance of Cleveland are the underlying reasons this area was settled and quickly thrived. Looking to a future of continued change, the four main pillars of the Vibrant NEO 2040 Plan provide a roadmap to position northeast Ohio communities for success:

1. Strengthen established communities

2. Increase transportation choice 
3. Preserve and protect natural resources

4. Promote collaboration and efficiency

Visiting the outdoors is the primary purpose of $11 \%$ of visitors to Cuyahoga County.

Cleveland Metroparks has illustrated a commitment to these pillars through work in the urban core and efforts to activate parks along area waterways and Lake Erie, provide trail connections, and to work with partners for initiatives throughout the region. Regional coordination includes revisiting the Connecting to Nature in Northeast Ohio plan from 2000 along with seven other area regional park system partners. The renewal of this effort documents progress and identifies priorities for the next fifteen years, exemplifying the regional efforts called for by Vibrant NEO 2040.

Cleveland Metroparks leadership and ability to deliver on commitments to the community has led to success with efforts such as the $\$ 7.95$ million-dollar TIGER grant, awards from local organizations, and recognition for agency best practices. These accomplishments fulfill the Progressive Era vision of highly a functional government. Cleveland Metroparks was recognized with the 2016 Vibrant City Impact Award by Cleveland Neighborhood Progress, a nationally highlighted community development organization dedicated to improving Cleveland by fostering inclusive communities of choice and opportunity. The award honors the Cleveland Metroparks support of placemaking and urban revitalization in Cleveland.

In addition to local involvement and recognition, Cleveland Metroparks demonstrates the highest standards of park management and operations nationally, receiving the National Recreation and Park Association Gold Medal Award for "Excellence in Park and Recreation Administration" in 1999, 2001, 2007, and 2016. Best practices are recognized through the agency's accreditation by the Commission for Accreditation of Park and Recreation Agencies (CAPRA), the Ranger Department's accredited by the Commission on Accreditation for Law Enforcement Agencies, Inc. (one of only six park districts across the nation) and the District's Government Finance Officers Association Distinguished Budget Presentation Award, received for 22 years.

Cleveland Metroparks proposes that the agency's foundation as an exemplary government agency provides ongoing returns to Greater Cleveland through stewardship and continued investment in natural capital. Investment in parks and trails is a stabilizing factor in the face of greater extremes in weather events and challenging economic times. The framework of parks is an equitable and enduring investment.

\section{REFERENCES}

[1] Definition from UN Conference on Sustainable Development, Natural Capital Declaration, 2 pp., 2012.

[2] Cramer, C.H., Newton D. Baker, a Biography, World Publishing: Cleveland and New York, 49 pp., 1961.

[3] Ohio Revised Code Title 15, Chapter 1545: Park Districts.

[4] Cleveland Metroparks 2016 Budget, Cleveland Metroparks: Cleveland, pp. 51, 60, 205, 24 Mar. 2016.

[5] Northeast Ohio Sustainable Communities Consortium, Vibrant NEO 2040 Vision, Framework, and Action Products for Our Future, 2013.

[6] The Trust for Public Land, The Economic Benefits of Cleveland Metroparks, Oct. 2013.

[7] Rockefeller Foundation, 100 Resilient Cities, http://www.100resilientcities.org/ resilience\#/-_. Accessed on: 17 Apr. 2017. 